\title{
MODERN DYNAMICS OF THE HEALTH OF THE POPULATION OF UKRAINE IN GLOBAL DIMENSION
}

\author{
Grebniak N.P., Taranov V.V., Fedorchenko R.A.
}

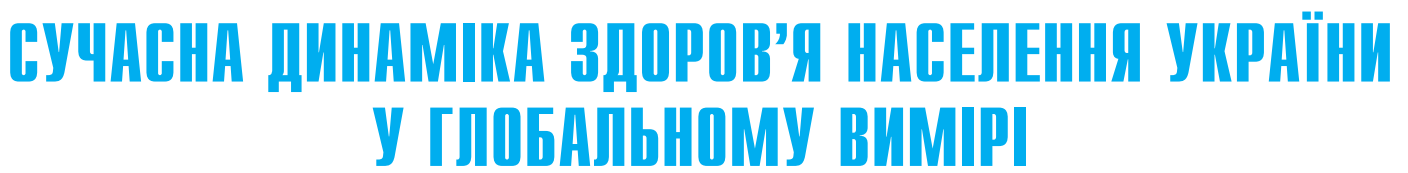

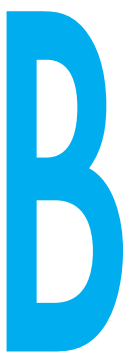

ГРЕБНЯК М.П., TAРАНОВ В.B., ФЕДОРЧЕНКО Р.А.

Запорізький державний медичний

університет,

м. Запоріжжя

УДК 614.1: 314.144

(477)

Ключові слова: здоров'я населення України,

смертність, тривалість життя, медико-соціальні фактори. ходження України у міжнародне медичне поле на тлі реформування системи охорони здоров'я диктує необхідність кардинальної зміни підходу до управління здоров'ям як ключового чинника соціально-економічного розвитку. Міжнародний досвід свідчить про найвищу перспективність поліпшення громадського та індивідуального здоров'я шляхом узгодженої діяльності усіх галузей держави. На перший план виступають стратегічні завдання визначення пріоритетів в охороні здоров'я у глобальному вимірі та встановлення національних особливостей його стану $[1,2,6,10,11]$.

Оцінка стану здоров'я населення $€$ однією 3 головних передумов планування лікувально-профілактичних заходів, обґрунтування форм і методів діяльності мережі закладів охорони здоров'я, оцінки ефективності роботи щодо збереження й зміцнення здоров'я населення [2, 4-6].

Мета дослідження - аналіз стану популяційного здоров'я населення України порівняно 3 показниками Європейського регіону та світу загалом.
Матеріали та методи дослідження. Дослідження проведене на підставі даних ВООЗ, щорічних звітів ЮНЕИДС, Державного комітету статистики України за 1990-2016 роки [3, 5, 9, 10, 12, 13]. Оцінка стану популяційного здоров'я на національному, європейському і світовому рівнях здійснювалася за показниками ВООЗ (смертність, тривалість життя, захворюваність, поширеність хвороб, медико-соціальні фактори), основними вимогами до яких $€$ валідність, специфічність, чутливість, надійність, репрезентативність, зрозумілість, доступність [3, 11]. Використано такі методи: аналітичний, статистичний, системного підходу, порівняльного аналізу. Статистичну обробку здійснювали відповідно до загальноприйнятих методів варіаційної статистики.

Результати та їх обговорення. Україна серед європейських держав відрізняється прискореними темпами депопуляції та її масштабністю. При цьому в останні десятиліття реєструється від'ємний режим відтворення населення, тобто неттокоефіцієнт менше 1,0 (все менше
СОВРЕМЕННАЯ ДИНАМИКА ЗДОРОВЬЯ НАСЕЛЕНИЯ УКРАИНЫ В ГЛОБАЛЬНОМ ИЗМЕРЕНИИ

Гребняк Н.П., Таранов В.В., Федорченко Р.А Запорожский государственный медицинский университет, г. Запорожье

Цель исследования - анализ популяционного здоровья населения Украины в сравнении с показателями Европейского региона и мира в целом.

Материалы и методы. Исследование проведено на основании данных ВОЗ, ежегодных отчетов ЮНЭЙДС, Государственного комитета статистики Украины за 1990-2016 годы. Оценка состояния популяционного здоровья на национальном, европейском и мировом уровнях осуществлялась по показателям ВОЗ (смертность, продолжительность жизни, заболеваемость, распространенность болезней, медико-социальные факторы), основными требованиями которых являются валидность, специфичность, чувствительность, надежность, репрезентативность, понятность, доступность. Использованы следующие методы: аналитический, статистический, системного подхода, сравнительного анализа.
Результаты. Установлено, что современному состоянию популяционного здоровья населения Украины свойственны выраженные негативные тенденции. Медико-демографическая ситуация характеризуется сверхвысокой смертностью, низким уровнем ожидаемой продолжительности жизни и демографическим постарением населения.

Выводы. Смертность населения Украины значительно выше уровня Европейского региона и характеризуется ее ростом в последние годы, особенно от инфекционных заболеваний и ВИЧ/СПИДа. Гендерной спецификой смертности в стране являются более высокие ее уровни у мужчин, а также низкая ожидаемая продолжительность жизни. К национальным особенностям медико-соци альных факторов риска для здоровья населения относятся высокие уровни потребления крепких алкогольных напитков, распространенность курения на фоне стабильно низкого финансирования охраны здоровья.

Ключевые слова: здоровье населения Украины, смертность, продолжительность жизни, медико-социальные факторы.

() Гребняк М.П., Таранов В.В., Федорченко Р.А. СТАТТЯ, 2018. 
дівчаток доживають до віку матерів, в якому вони були народжені). Слід зазначити, що трансформація вікової структури в Україні наближає «кризу старіння». Протягом 1990-2016 років індекс старіння (співвідношення осіб старше 65 років і 100 дітей віком до 15 років) зріс майже удвічі. Україна входить до складу 30 найстаріших держав світу. Зокрема, 22, $1 \%$ населення - старше працездатного віку, а це за індексом старіння шкали $\mathrm{OOH}$ - дуже старе населення [10]. За результатами аналізу, материнська смертність в Україні протягом 20012010 років вища за європейський рівень, але значно нижче світового (табл. 1).

Коефіцієнт материнської смертності, зумовленої обтяженою вагітністю або ії̈ веденням, у державі перевищував європейські значення в 1,31,6 рази $(p<0,05)$. За усередненими даними материнської смертності за 2010-2012 роки Україна посідає 9-10 місце серед 53 європейських країн. її основними причинами були екстрагенітальна патологія та кровотечі. Однією 3 передумов вказаного може бути «постаріння» материнства. Зокрема, останнім часом інтенсивність народжуваності жінками віком 35-39 років зросла майже втричі.
Аналогічний характер також мали стандартизовані за віком коефіцієнти смертності усього населення через загальні причини. В Україні рівні смертності через неінфекційні захворювання та травми були суттєво вищими порівняно з Європейським регіоном і світом загалом. Підтвердженням вказаного є стандартизований за віком коефіцієнт передчасної смертності людей віком 30-69 років через основні неінфекційні хвороби. Так, смертність через чотири хвороби (серцево-судинні захворювання, рак, цукровий діабет, хронічні респіраторні хвороби) в Україні перевищувала середньоєвропейський рівень на 262,9 вип./100 тис. $(p<0,05)$.

Загальною закономірністю сучасної динаміки вказаних показників було зниження їх рівня в усіх державах. Особливістю динаміки смертності через інфекційні захворювання в Україні, на відміну від Європейського регіону та світу, $\epsilon$ її зростання в 1,5 рази $(p<0,05)$. Це зумовило те, що стандартизований за віком коефіцієнт смертності в Україні нині майже в 2 рази вищий за середньоєвропейський. Загальний коефіцієнт смертності усього населення в Україні також залишається одним 3 найвищих в Європі та світі. Особливо він високий у сільській місцевості (17,1-17,9\%о).

Протягом 2014-2016 років основними причинами смерті в Україні були хвороби системи кровообігу (920,3-989,8 вип./100 тис.), новоутворення (184,9195,1 вип./100 тис.). Специфічною рисою стандартизованих за віком коефіцієнтів смертності населення у віці $30-70$ років $\epsilon$ вищий рівень смертності через новоутворення (на 4 вип./100 тис. порівняно з Європою та на 20 вип./100 тис. у світі). Коефіцієнт смертності через серцево-судинні захворювання у державі також перевищив аналогічні показники у 2,0 рази $(p<0,05)$. При цьому чоловіки відносно молодого віку (30-44 роки) вмирають у 6 разів частіше, ніж в $€ C$, тобто вмирають значно раніше. В Україні також вищим за середньоєвропейський рівень був коефіцієнт смертності внаслідок хронічних респіраторних захворювань (в 1,8 рази, $p<0,05$ ) за нижчого світового рівня (у 2,2 рази, $p<0,05)$. Вказане зумовило вірогідно вищий стандартизований коефіцієнт смертності через усі причини (в 1,9 рази) порівняно 3 середньоєвропейським та середньосвітовим (в 1,6 рази) рівнями. Встановлені особливості коефіцієнтів смертності в Україні свідчать, що її населення не доживає до «ракового» віку, а вмирає раніше 3 інших причин.

\section{Смертність населення}

Таблиця 1

\begin{tabular}{|c|c|c|c|c|c|c|}
\hline \multirow{2}{*}{ Показник } & \multicolumn{2}{|c|}{ Україна } & \multicolumn{2}{|c|}{ Європейський регіон } & \multicolumn{2}{|c|}{ Світ загалом } \\
\hline & $2001 \mathrm{p}$. & $2010 \mathrm{p}$. & $2001 \mathrm{p}$. & $2010 \mathrm{p}$. & $2001 \mathrm{p}$. & 2010 p. \\
\hline $\begin{array}{l}\text { Коефіцієнт материнської смертності } \\
\text { (на } 100 \text { тис. новонароджених) }\end{array}$ & 35 & 32 & 27 & 20 & 320 & 210 \\
\hline \multicolumn{7}{|c|}{ Стандартизовані за віком коефіцієнти смертності через загальні причини (на 100 тис. населення) } \\
\hline Інфекційні захворювання & 61 & 94 & 62 & 51 & 275 & 230 \\
\hline Неінфекційні захворювання & 881 & 823 & 590 & 532 & 612 & 573 \\
\hline Травми & 130 & 112 & 79 & 63 & 93 & 78 \\
\hline \multicolumn{7}{|c|}{ Коефіцієнт смертності (на 100 тис. населення) } \\
\hline ВІЛ/СНІД & 19 & 49 & 11 & 11 & 30 & 25 \\
\hline ТБ серед ВІЛ негативного населення & 21 & 18 & 8 & 5 & 21 & 14 \\
\hline \multicolumn{7}{|c|}{ Розподіл причин смерті серед дітей до 5 років (\%) } \\
\hline Пневмонія & 16 & 12 & 14 & 12 & 18 & 18 \\
\hline Недоношеність & 17 & 16 & 20 & 21 & 12 & 17 \\
\hline Родова асфіксія & 7 & 8 & 9 & 9 & 9 & 10 \\
\hline Неонатальний сепсис & 4 & 4 & 3 & 4 & 8 & 6 \\
\hline Вроджені аномалії & 24 & 28 & 17 & 17 & 4 & 7 \\
\hline Травми & 9 & 9 & 6 & 6 & 3 & 5 \\
\hline Інші захворювання & 23 & 23 & 31 & 31 & 46 & 37 \\
\hline
\end{tabular}




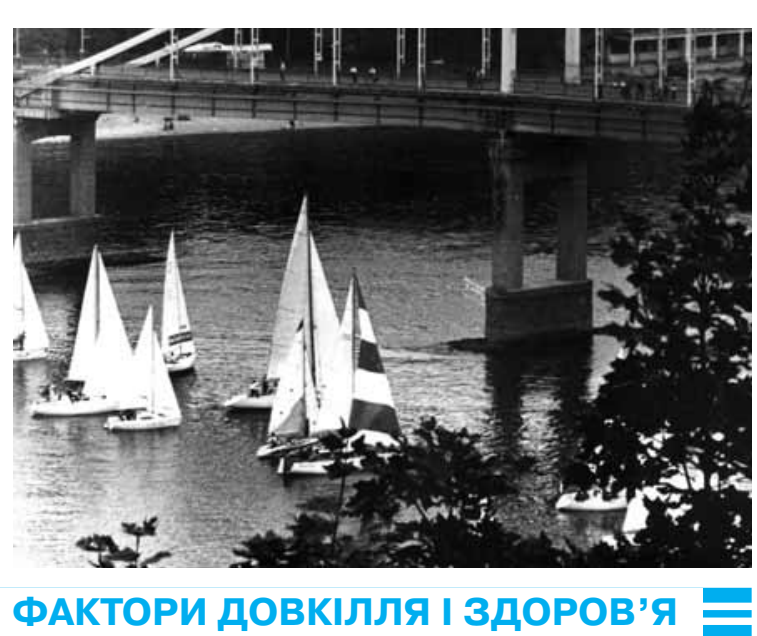

Непрямим доказом також $€$ висока питома вага хворих 3 занедбаними стадіями злоякісних новоутворень в Україні серед вперше захворілих (58-60\%) порівняно з 5-7\% в ЄС.

Вкрай негативним явищем у державі $€$ сучасна динаміка коефіцієнта смертності через ВІЛ/СНІД (темп зростання - 2,6 рази). Внаслідок чого цей показник 2010 року перевищив середньоєвропейський (у 4,4 рази) та середньосвітовий рівні (у 2,0 рази). Тягар епідемії ВІЛ-інфекції в Україні посилюється поєднанням її патології з туберкульозом. Протягом 2006-2016 років цей показник зріс у 2,7 рази, а за розрахунками ВОО3 - у 4,2 рази.

Загальною світовою закономірністю сучасної динаміки коефіцієнта смертності через туберкульоз серед ВІЛ-негативного населення $€$ його зниження. Проте в Україні вона мала лише характер тенденції. Внаслідок вказаного коефіцієнт смертності в Україні став найвищим порівняно 3 Європейським регіоном (у 3,6 рази) та світом (в 1,3 рази). Захворюваність на туберкульоз в Україні протягом останніх років також була вищою, ніж в Європі в 1,4-2,1 рази. Понадвисока смертність через туберкульоз в Україні зумовлена високими рівнями захворюваності, значною питомою вагою соціально незахищених верств населення, мультирезистентних форм туберкульозу та регіональними його особливостями й складом населення [6, 9]. Так, захворюваність на туберкульоз в Україні протягом останніх років вища за середньоєвропейський рівень в 1,42,1 рази. Між тим, за розрахунками експертів, реальна захворюваність на туберкульоз в Україні становить 91,1 вип./100 тис., що вище офіційного рівня в 1,3 рази. Вказане виносить за межі реальності досягнення мети глобальної стратегії ВООЗ «Покласти кінець ТБ», якою передбачено зниження до 2035 року рівня захворюваності менше 10 вип./100 тис. Серед вперше захворілих понад дві третини складають особи із соціально незахищених верств. Захворюваність серед сільського населення переважає міське в 1,3 рази. За рівнем поширеності мультирезистентних форм туберкульозу наша країна посідає перше місце в Європейському регіоні та 4-те місце у світі. Україна належить до 27 держав світу, в яких зосереджено 85\% усього тягаря мультирезистентних форм [3, 12, 13]. Загалом первинна хіміорезистентність збудників туберкульозу до основних протитуберкульозних препаратів становить 25-30\%, вторинна $70 \%$.

Розподіл втрачених років життя за загальними причинами в Україні відповідає європейській структурі - неінфекційні захворювання (70-73\%), травми (17-20\%), інфекційн захворювання (10-12\%). Особливістю розподілу втрачених років життя у світі $€$ домінування інфекційних захворювань (51\%) на тлі менш значної питомої ваги неінфекційних захворювань (35\%).

У формуванні рівня смертності населення особливе місце належить дітям до 5 років. При цьому в Україні вона у 25 разів вища, ніж у країнах з найнижчими показниками в Європі. На стандартизовані показники смертності дітей до 5-річного віку також суттєво впливає дохід населення. Зокрема, у країнах 3 доходами нижче середніх він у 26,9 разів вищий за середньоєвропейський рівень.

Структурі причин смертності серед дітей до 5 років протягом 2000-2010 років властива відносна стабільність, за винятком зростання питомої ваги через вроджені аномалії в Україні (на 16,7\%) і у світі (на $7,5 \%)$ та недоношеності у світі (на 41,7\%). До особливостей структури в Україні також належить значна питома вага смертності через вроджені аномалії - на $11,0 \%$ вище, ніж в Європі та на $21 \%$, ніж у світі.

До гендерної специфіки смертності належать більш високі її коефіцієнти у чоловіків в усіх популяціях порівняно 3 жінками. При цьому смертність в Україні, що зумовлена статтю, в усіх вікових групах найбільш виражена, а саме: на 28,6\% серед немовлят, на 58,3\% серед дітей до 5-тирічного віку, у 2,6 рази - у віці 15-60 років. Вона вірогідно вища за середньоєвропейське та середньосвітове значення $(p<0,05)$. Особливо значні розбіжності вказаного коефіцієнта реєструються у віці 15-60 років: у 2,6 рази - в Україні, у 2,3 рази - в Європі, в 1,5 рази - у світі). До національних особливостей також належить зростання гендерних тенденцій з віком, тоді як в Європейському регіоні та у світі загалом коефіцієнти смертності немовлят та дітей до 5-тирічного віку за статтю суттєво не відрізняються.

Негативні тенденції у смертності в Україні, на думку експертів, зумовлені складним комплексом чинників: кризовим станом системи охорони здоров'я внаслідок глибоких соціально-економічних змін, низьким рівнем життя, знеціненням здоров'я з боку держави й громадян [6, 9].

Високі коефіцієнти смертності в Україні, особливо у чоловіків, детермінують низькі рівні очікуваної тривалості життя (табл. 2).

Так, ймовірність дожити від 15 до 60 років у чоловіків України становить 62\%, тоді як у Західній Європі - понад 90\%. За рівнем очікуваної тривалості життя Україна перебуває у зоні мінімальних регіональних значень. Зокрема, за очікуваною тривалістю життя при народженні вона посідає 3-4 місця. Відомо, що негативна динаміка, тобто менша очікувана тривалість життя пов'язана 3 підвищеною смертністю через серцево-судинні захворювання, цукровий діабет, деменції та ожиріння $[4,12$, 13]. До вагомих причин змен- 
шення очікуваної тривалості життя також належить дохід населення. Зокрема, у країнах ЄС $з$ доходом населення нижче середнього очікувана тривалість життя при народженні менша на 8 років у чоловіків та на 11 років - у жінок. За даними Всесвітнього банку, Україна входить до четвірки європейських країн 3 рівнем доходів нижче середнього [7]. Динаміка очікуваної тривалості життя при народженні протягом 1990-2011 років в $\Theta_{\text {в- }}$ ропейському регіоні та у світі мала тенденцію до зростання на 4-6 років, тоді як в Україні вона була відносно стабільною.

Отже, очікувана тривалість життя у чоловіків при народженні дуже низька за європейськими стандартами, і це її відставання збільшується, сягаючи 7 років. Менш виражене відставання спостерігається у жінок. Основною причиною нижчої тривалості життя є зростання смертності через хвороби системи кровообігу. Специфікою держави є те, що до похилого віку більшість населення має низку різноманітних патологічних відхилень, накопичує хронічні захворювання, що зумовлює збільшення біологічного віку. Внаслідок цього зростає обсяг медико-соціальної допомоги, знижуеться якість робочої сили. Показник HALE (очікувана тривалість здорового життя) України був меншим за середньоєвропейський (на 11 років у чоловіків та на 6 років у жінок) і середньосвітовий (на 3 роки у чоловіків) рівні. Дещо вищим HALE був у жінок України порівняно зі світовим.

При аналізі медико-соціальних факторів ризику встановлено високу їх поширеність (табл. 3).

На високу поширеність шкідливих звичок вказує значний рівень споживання алкоголю дорослими. Так, середньорічне споживання алкоголю протягом 2001-2011 років становить в Україні 8,5-9,1 л чистого алкоголю, що в 1,5-1,9 рази перевищує середньосвітовий. За рівнем загального споживання алкогольних напоїв Україна входить до першої десятки самих питущих країн світу. Характерною рисою моделі споживання в Україні $€$ акцент на споживання міцних алкогольних напоїв, що суттєвим чином відрізняється від моделі країн ЄC (перевага надається слабоалкогольним напоям 3 менш шкідливим впливом на здоров'я). Свідченням вагомості алкогольної проблеми у державі є поширеність розладів психіки та пове- дінки через вживання алкоголю. Так, під профілактичним та диспансерним наглядом через це 2015 року перебувало 1416, 1 осіб/100 тис. При цьому пряма алкогольна смертність (отруєння етанолом, алкогольні цирози печінки, алкогольні психози) становить 1,6\% від загальної смертності.

Істотну шкоду здоров'ю завдає куріння. Між тим, його поширеність серед чоловіків найвища порівняно 3 Європейським регіоном та зі світом. Незважаючи на загальну тенденцію його зниження поширеність залишається найвищою (в 1,2 та 1,4 рази відповідно). В Україні палить половина чоловіків. Більш вражаюча та більш сприятлива тенденція - зниження поширеності куріння спостерігається серед жінок в Україні. Але при цьому палить майже кожна сьома жінка. Слід відзначити, що поширеність куріння в Україні 2016 року зросла на 5\% порівняно з 2015. На формування ранньої залежності від тютюну вказує стабільність поширення куріння серед підлітків 13-15 років. В Україні найвища поширеність куріння і серед юнаків, і серед дівчат (у 1,5 рази). Середній вік початку куріння у хлопців - 1314 років, 11-12 років - у дівчат. Таким чином, тютюнопаління

Смертність та очікувана тривалість життя у динаміці 1990-2015 років

Таблиця 2

\begin{tabular}{|c|c|c|c|c|c|c|c|c|}
\hline \multirow{2}{*}{ Показник } & \multicolumn{4}{|c|}{ Чоловіки } & \multicolumn{4}{|c|}{ Жінки } \\
\hline & $1990 p$ & $2000 p$ & $2008 p$ & 2011 p. & 1990 p. & 2000 p. & 2008 p. & $2011 p$ \\
\hline \multicolumn{9}{|c|}{ Україна } \\
\hline Коефіцієнт смертності немовлят, \%о & 22 & 20 & 16 & $9 *$ & 14 & 13 & 11 & $7^{\star}$ \\
\hline Коефіцієнт смертності дітей до 5 років, \%о & 26 & 24 & 19 & & 16 & 14 & 12 & \\
\hline $\begin{array}{l}\text { Коефіцієнт смертності дорослих } \\
15-60 \text { років, на } 100 \text { тис. }\end{array}$ & 287 & 377 & 399 & 310 & 112 & 136 & 151 & 120 \\
\hline Очікувана тривалість життя при народженні, р. & 66 & 62 & 62 & 65 & 75 & 73 & 74 & 76 \\
\hline \multicolumn{9}{|c|}{ Європейський регіон } \\
\hline Коефіцієнт смертності немовляті, \%о & 30 & 14 & 18 & 10 & 24 & 16 & 10 & - \\
\hline Коефіцієнт смертності дітей до 5 років, \%о & 36 & 24 & 15 & - & 29 & 19 & 12 & - \\
\hline $\begin{array}{l}\text { Коефіцієнт смертності дорослих } \\
15-60 \text { років, на } 100 \text { тис. }\end{array}$ & 215 & 229 & 208 & 183 & 97 & 98 & 90 & 81 \\
\hline Очікувана тривалість життя при народженні, р. & 68 & 68 & 71 & 72 & 75 & 77 & 79 & 79 \\
\hline \multicolumn{9}{|c|}{ Світ загалом } \\
\hline Коефіцієнт смертності немовлят, \%о & 63 & 55 & 46 & - & 60 & 52 & 43 & - \\
\hline Коефіцієнт смертності дітей до 5 років, \%о & 90 & 79 & 68 & & 89 & 78 & 65 & \\
\hline $\begin{array}{l}\text { Коефіцієнт смертності дорослих } \\
15-60 \text { років, на } 100 \text { тис. }\end{array}$ & 246 & 239 & 213 & 190 & 173 & 163 & 146 & 129 \\
\hline Очікувана тривалість життя при народженні, р. & 62 & 64 & 66 & 68 & 66 & 68 & 70 & 72 \\
\hline
\end{tabular}

Примітка: ${ }^{*} 2015$ рік. 
MODERN DYNAMICS OF THE HEALTH OF THE POPULATION OF UKRAINE IN GLOBAL DIMENSION Grebniak N.P., Taranov V.V., Fedorchenko R.A. Zaporizhzhia State Medical University, Zaporizhzhia

Objective: We analyzed the population health of the population of Ukraine in comparison with the indicators of the European region and throughout the world.

Materials and methods: The study was carried out on the basis of WHO data, annual reports of UNAIDS, the State Statistics Committee of Ukraine for 1990-2016. The assessment of the state of population health at the national, European and world levels was carried out according to WHO indicators (mortality, life expectancy, incidence, prevalence of diseases, medico-social factors) which main requirements are validity, specificity, sensitivity, reliability, representativeness, intelligibility, accessibility. We used analytical, statistical, system approach, comparative analysis trends methods.
Results: The pronounced negative tendencies were established to be typical for the current state of demographic situation is characterized by an extremely high mortality, a low level of life expectancy and a demographic aging of the population.

Conclusions: The death rate of the population of Ukraine is significantly higher than the level in the European Region and is characterized by its growth last years, especially due to the infectious diseases and HIV/AIDS. A higher death rate in men and a low life expectancy are the gender specificities of mortality in the country. The high levels of the consumption of strong alcoholic beverages, the prevalence of smoking against the background of consistently low financing for health care are the national features of medico-social risk factors for the health of the population.

Keywords: health of the population of Ukraine, mortality, life expectancy, medico-social factors. залишається однією з головних причин, що сприяють смерті через неінфекційні захворювання.

Формування системи охорони здоров'я визначається достатністю обсягу фінансування галузі медицини. Нині фінансове забезпечення охорони здоров'я здійснюється 3 трьох джерел: державних (оподаткування), соціальних (цільові внески суспільних фондів медичного страхування) та приватних (особисті кошти фізичних та юридичних осіб). Загальні витрати на охорону здоров'я від внутрішнього валового продукту в Україні в останній період зросли на 0,8\% (табл. 4). Проте вони, як і раніше, залишаються значно нижчими, ніж в Європейському регіоні (на 9,3\%) та у світі (на 9,2\%). При цьому загальні державні витрати на охорону здоров'я у державі нижчі за середньоєвропейські та світові в 1,4 рази.

Частка бюджету на охорону здоров'я протягом 2007-2014 років зменшилася до 50,8\%. Питома вага державних витрат у світі вища на 8,9\%. В Європі вона становить три чверті у загальних витратах на охорону здоров'я. Рівень загальних витрат на охорону здоров'я протягом 2007-2014 років в Україні залишався стабільним при зростанні його в Європейському регіоні та у світі. При цьому він був нижчим за середньоєвропейський у 10,9 разів і у 4,6 рази - за світовий. Державні витрати на охорону здоров'я також бути меншими, ніж в Європейському регіоні та у світі відповідно у 9,9 та 3,4 рази.

Таким чином, кризові явища у популяційному здоров'ї населення України диктують необхідність нагального реформування системи здоров'я. До пріоритетних завдань з охорони здоров'я у державі належать зниження впливу зовнішніх причин смерті та витіснення смертності через серцево-судинні захворювання у більш пізній вік. Основні профілактичні заходи полягають у першочерговості лікувально-профілактичної роботи у групах ризику, формуванні здорового способу життя, розробці й впровадженні у практику профілактично-оздо- ровчих технологій, створенні системи гігієнічної донозологічної діагностики захворювань, поліпшенні соціального клімату. Безумовним підґрунтям подолання кризових явищ у здоров'ї населення України є поліпшення екологічної ситуації, створення здорових умов праці, навчання та протидія епідеміям ВІЛ/СНІДу, туберкульозу і гепатиту.

\section{Висновки}

1. Смертність населення України значно перевищує рівні Європейського регіону. У державі сформувалася консервативна структура причин смерті зі специфічною рисою поєднання високого рівня смертності через хвороби органів кровообігу (ендогенні причини) 3 хворобами органів дихання, травмами, інфекційними й паразитарними хворобами (екзогенні причини). Сучасна динаміка смертності в Україні, на відміну від Європейського регіону і світу, характеризується зростанням, а також суттєвим внеском частки інфекційних захворювань та ВІЛ/СНІДу.

Медико-соціальні чинники ризику

Таблиця 3

\begin{tabular}{|c|c|c|c|c|c|c|}
\hline \multirow{2}{*}{ Показник } & \multicolumn{2}{|c|}{ Україна } & \multicolumn{2}{|c|}{ Європейський регіон } & \multicolumn{2}{|c|}{ Світ } \\
\hline & 2001 p. & 2011 p. & 2001 p. & $2011 \mathrm{p}$. & $2001 \mathrm{p}$. & $2011 \mathrm{p}$. \\
\hline $\begin{array}{l}\text { Споживання алкоголю дорослими >15 років, } \\
\text { л чистого алкоголю }\end{array}$ & 8,5 & 9,1 & 9,5 & 10,1 & 4,4 & 6,0 \\
\hline $\begin{array}{l}\text { Поширеність куріння серед дорослих }>15 \text { років, \% } \\
\text { чоловіки } \\
\text { жінки }\end{array}$ & $\begin{array}{l}65 \\
24\end{array}$ & $\begin{array}{l}50 \\
13\end{array}$ & $\begin{array}{l}45 \\
24\end{array}$ & $\begin{array}{l}41 \\
22\end{array}$ & $\begin{array}{r}41 \\
9\end{array}$ & $\begin{array}{c}36 \\
8\end{array}$ \\
\hline $\begin{array}{l}\text { Поширеність куріння серед підлітків 13-15 років, \% } \\
\text { юнаки } \\
\text { дівчата }\end{array}$ & $\begin{array}{l}30 \\
22\end{array}$ & $\begin{array}{l}30 \\
22\end{array}$ & $\begin{array}{l}21 \\
17\end{array}$ & $\begin{array}{l}20 \\
15\end{array}$ & $\begin{array}{l}18 \\
10\end{array}$ & $\begin{array}{l}18 \\
11\end{array}$ \\
\hline
\end{tabular}

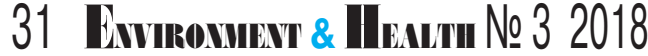


2. Гендерною специфікою смертності у державі $€$ більш виражена смертність серед чоловіків в усіх вікових групах порівняно з Європейським регіоном та світом загалом. До національних особливостей смертності чоловіків належать зростання її 3 віком, а також дуже низька за європейськими стандартами очікувана тривалість їхнього життя.

3. Медико-соціальним факторам ризику для здоров'я населення притаманні високий рівень споживання міцних алкогольних напоїв та значна поширеність куріння серед чоловіків. Рівень витрат на охорону здоров'я в Україні нині перебуває на стабільно низькому рівні.

ЛІТЕРАТУРА

1. Гребняк Н.П, Агарков В.А., Грищенко С.В. и др. Здоровье населения Украины в глобальном измерении. Профілактична медицина. 2012. T. XII, № 1. С. 128-134.

2. Слабкий Г.О., Лехан В.М., Надутий К.О. та ін. Деякі уроки реформи охорони здоров'я України. Україна. Здоров'я нації. 2014. № 3. С. 7-22.

3. Європейська база даних «Здоров'я для всіх». URL : http://www. euro. who.int/hfadb.

4. Здоров'я 2020. Основи європейської політики та стратегія для XXI ст. Copenhagen : WHO, Regional Office for Europe, 2013. 224 p.

5. Показники здоров'я населення та використання ресурсів охорони здоров'я в Україні за 2013-2014 роки. Київ : ЦМС МО3 України, 2015. 328 с.

6. Слабкий Г.О., Дудник С.В., Дудіна О.О., Габорець С.Р. Загальна характеристика стану здоров'я населення України. Регіональні системи охорони здоров'я України 2014 рік. Київ, 2015. Ч. І. С. 6-26.

7. Герасименко Г.В. Особливості міжнародного досвіду вимірювання людського розвитку на субнаціональному рівні. Демографія та соціальна економіка. 2017. № 1 (29). С. 11-23.

8. Чепелевська Л.А., Орда О.М. Новітні регіональні тенденції

Таблиця 4

Витрати на охорону здоров'я

\begin{tabular}{|c|c|c|c|}
\hline Показник & Україна & $\begin{array}{c}\text { Європейський } \\
\text { регіон }\end{array}$ & Світ \\
\hline $\begin{array}{l}\text { Загальні витрати на охорону здоров'я } \\
\text { від валового внутрішнього продукту, \% } \\
2000 \text { р. } \\
2007 \text { р. } \\
2010 \text { р. } \\
2014 \text { р. }\end{array}$ & $\begin{array}{l}5,9 \\
6,9 \\
7,1 \\
7,8\end{array}$ & $\begin{array}{l}8,4 \\
8,8 \\
9,3\end{array}$ & $\begin{array}{l}9,2 \\
9,7 \\
9,2\end{array}$ \\
\hline $\begin{array}{l}\text { Загальні державні витрати на охорону } \\
\text { здоров'я від загальних державних } \\
\text { витрат, \%: } \\
2000 \text { р. } \\
2007 \text { р. } \\
2014 \text { р. }\end{array}$ & $\begin{array}{c}8,4 \\
9,2 \\
10,8\end{array}$ & $\begin{array}{l}14,3 \\
15,3 \\
14,8\end{array}$ & $\begin{array}{l}14,5 \\
15,5 \\
15,1\end{array}$ \\
\hline $\begin{array}{l}\text { Загальні державні витрати на охорону } \\
\text { здоров'я від загальних витрат } \\
\text { на охорону здоров'я, \% } \\
2000 \text { р. } \\
2007 \text { р. } \\
2014 \text { р. }\end{array}$ & $\begin{array}{l}48,9 \\
57,6 \\
50,8\end{array}$ & $\begin{array}{l}75,3 \\
76,0 \\
74,4\end{array}$ & $\begin{array}{l}57,9 \\
59,6 \\
58,9\end{array}$ \\
\hline $\begin{array}{l}\text { Загальні витрати на охорону здоров’я } \\
\text { на душу населення, долари США } \\
2000 \text { р. } \\
2007 \text { р. } \\
2014 \text { р. }\end{array}$ & $\begin{array}{c}38 \\
210 \\
203\end{array}$ & $\begin{array}{c}931 \\
2035 \\
2217\end{array}$ & $\begin{array}{l}481 \\
802 \\
941\end{array}$ \\
\hline $\begin{array}{l}\text { Державні витрати на охорону здоров'я } \\
\text { на душу населення, долари США } \\
2000 \text { р. } \\
2007 \text { р. } \\
2011 \text { р. }\end{array}$ & $\begin{array}{c}19 \\
121 \\
170\end{array}$ & $\begin{array}{c}701 \\
1546 \\
1679\end{array}$ & $\begin{array}{l}279 \\
478 \\
571\end{array}$ \\
\hline $\begin{array}{l}\text { Валовий національний дохід на душу } \\
\text { населення, міжнародні долари } \\
1990 \text { р. } \\
2000 \text { р. } \\
2008 \text { р. } \\
2011 \text { р. }\end{array}$ & $\begin{array}{l}5950 \\
3170 \\
7210 \\
7040\end{array}$ & $\begin{array}{l}11546 \\
15193 \\
22849 \\
25210\end{array}$ & $\begin{array}{c}4862 \\
6940 \\
10290 \\
11536\end{array}$ \\
\hline
\end{tabular}

смертності населення України. Україна. Здоров'я нації. 2011. № 2. С. 68-73.

9. Щорічна доповідь про стан здоров'я населення, санітарноепідемічну ситуацію та результати діяльності системи охорони здоров'я України. 2016 рік / МОЗ України, ДУ «УІСД МОЗ України». Київ, 2017. 516 с. 10 . Early years, family and education task group: report. European review of social determinants and the health divide in the WHO European Region / B. Jensen, C. Currie, A. Dyson, N. Eisenstadt, E. Melhuish (editors). Copenhagen : WHO Regional Office for Europe; 2013.

URL : http://www.euro.who.int/ data/assets/pdf file/0006/2361 93/Early-years, -family-and-education-task-group-report.pdf

11. Improving the lives of children and young people: Case studies from Europe. Vol. 1 Early years. Copenhagen: WHO Regional Office for Europe, 2013. URL : http://www.euro. who.int/en/publications/ abstracts/improving-the-livesof-children-and-young-peoplecase-studies-from-europe.-volume-1.-early-years.

12. World Health Statistics 2013. Part III. Global Health Indicators. Geneva : WHO Press, 2013. $139 \mathrm{p}$

13. World Health Statistics 2015. Part II. Global Health Indicators. Geneva : WHO Press, 2015. P. 125-135.

\section{REFERENCES}

1. Grebniak N.P., Agarkov V.A., Grishchenko S.V. et al. Zdorovie naseleniia Ukrainy v globalnom izmerenii [Health of the Population of Ukraine in the Global Dimension]. Profilaktychna meditsina. 2012 ; XII (1) : 128134 (in Ukrainian).

2. Slabkyi H.O., Lekhan V.M., Nadutyi K.O. et al. Deiaki uroky reformy okhorony zdorovia Ukrainy [Some Lessons in Health Care Reform in Ukraine]. Ukraina. Zdorovia natsii. 2014; 3 : 7-22 (in Ukrainian).

3. European Health for All family of databases. URL : http://www. euro. who.int/hfadb.

4. Zdorovia 2020. Osnovy yevropeiskoi polityky ta stratehiia dlia XXI st. [Health 2020.

Fundamentals of European Policy and Strategy for the 21-st Century]. Copenhagen : WHO ; 2013 : 224 p. (in Ukrainian).

5. Ministry of Public Health of Ukraine. Pokaznyky zdorovia 
naselennia ta vykorystannia resursiv okhorony zdorovia $v$ Ukraini za 2013-2014 roky. [Indicators of Public Health and the Use of Health Care Resources in Ukraine for 2013-2014]. Kyiv ; 2015 : 328 p. (in Ukrainian).

6. Slabkyi H.O., Dudnyk S.V., Dudina O.O., Haborets S.R. Zahalna kharakterystyka stanu zdoroviia naselennia Ukrainy [General Characteristics of the Health Status of the Population of Ukraine]. Rehionalni systemy okhorony zdoroviia Ukrainy 2014 rik. Kyiv ; 2015 (I) : 6 -26 (in Ukrainian).

7. Herasymenko H.V. Demohrafiia ta sotsialna ekonomika. 2017 ; 1 (29) : 11-23 (in Ukrainian).

8. Chepelevska L.A. and Orda O.M. Ukraina. Zdorovia natsii. 2011; 2 : 68-73

(in Ukrainian).

9. Shchorichna dopovid pro stan zdorovia naselennia, sanitarno-epidemichnu sytuatsiiu ta rezultaty diialnosti systemy okhorony zdorovia Ukrainy. 2016 rik [Annual Report on the State of Health of the Population, Sanitary and Epidemiological Situation and Results of the Health Care System of Ukraine. 2016 year]. Ministry of Health of Ukrainy ; DU «UISD MOZ Ukrainy». Kyiv ; 2017 : 516 p. (in Ukrainian).

10. Early Years, Family and Education Task Group: Report. European Review of Social Determinants and the Health Divide in the WHO European Region / B. Jensen, C. Currie, A. Dyson, N. Eisenstadt, E. Melhuish (editors). Copenhagen : WHO Regional Office for Europe ; 2013. URL : http://www. euro.who.int/data/assets/ pdf file/0006/236193/Earlyyears, -family-and-educationtask-group-report.pdf

11. Improving the Lives of Children and Young People: Case Studies from Europe. Vol. 1. Early Years. Copenhagen : WHO Regional Office for Europe ; 2013. URL : http:// www. euro. who.int/en/publications/abstracts/improving-thelives-of-children-and-youngpeople-case-studies-fromeurope--volume-1. -early-years.

12. World Health Statistics 2013. Part III. Global Health Indicators. Geneva : WHO ; 2015 : 139 p.

13. World Health Statistics 2015. Part II. Global Health Indicators. Geneva : WHO ; 2015 : $125-135$.

Надійшло до редакції 24.05.2018

\section{EXIERNAL CAUSES OF MORTALITY IN UKRAINE: STANDARDIZED RISKS AND LOST PROFIT}

Kartashova S.S., Kaneva T.V., Omelchenko E.M., Polka O.O.

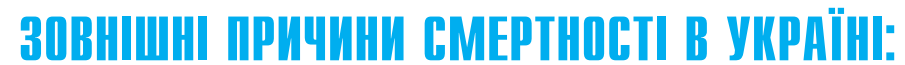
СТАНДАРТИЗОВАНІ РИЗИКИ ТА УПУЩЕНА ВИГОДА
1КАРТАШОВА C.C., 1 KAHEBA T.B., 2ОМЕЛЬЧЕНКО Е.М., 2ПОЛЬКА 0.0.

${ }^{1}$ Київський національний торгово-економічний університет, м. Київ, 2ДУ «Інститут громадського здоров'я ім. О.М. Марзєєва НАМН України», м. Київ УДК 614.1/2: $314.18: 314.4$

Ключові слова: смертність, зовнішні причини смерті, втрачені роки потенційного життя, стандартизована структура, відносний ризик, упущена вигода. івень смертності у різних статево-вікових групах населення істотно відрізняється і залежить від сполученої дії чинників, серед яких виділяють ендогенні фактори, пов'язані з природним старінням організму, особливостями його фізіології, спадковості, психотипу, та екзогенні, що зумовлені впливом зовнішнього середовища, тобто соціально-економічною та екологічною ситуацією, рівнем розвитку охорони здоров'я, осо-
ВНЕШНИЕ ПРИЧИНЫ СМЕРТНОСТИ В УКРАИНЕ:

СТАНДАРТИЗИРОВАННЫЕ РИСКИ И УПУЩЕННАЯ ВЫГОДА

${ }^{1}$ Карташова С. С., ${ }^{1}$ Канева Т.В., 2 Омельченко Э.М., 2 Полька Е.А.

1 Киевский национальный торгово-экономический университет, г. Киев, 2 ГУ «Институт общественного здоровья им. А.Н. Марзеева НАMН Украины», г. Киев

По уровню смертности от внешних причин Украина более чем в два раза опережает страны Европейского Союза. Роль внешних причин в нашем государстве недооценивается и недостаточно учитывается при определении приоритетов политики, направленной на снижение смертности и увеличение продолжительности жизни.

Цель исследования заключалась в определении демографических и социально-экономических потерь государства от внешних причин смерти (МКБ-10: V01-Y98), в том числе и по их отдельным нозологиям (МКБ-10: X45, V01-V99, Х60-Х84).

Материалы и методы. В качестве источников первичной информации использованы данные системы национальных счетов, форм государственной статистической отчетности: ф. С-8 «Распределение умерших по полу, возрастным группам и причинам смерти», ф. A-1 "Общие итоги естественного движения» и информация

Министерства финансов Украины о значении учетной ставки НБУ. Результаты. Согласно классической структуре смертности внешние причины занимают третье ранговое место после болезней системы кровообращения и новообразований, в то время как по показателю ПГПЖ - второе, при этом их удельный вес увеличился в 3,7 раза. Последнее обусловлено тем, что средний возраст умерших от внешних причин в 1,9 раза меньше, чем у тех, кто умер от болезней системы кровообращения. Среди всех внешних причин смерти особое внимание следует уделить ДТП, случайным отравлениям и действию алкоголя, суицидам. Их удельный вес среди внешних причин составляет $50 \%$. При анализе и оценке структурных сдвигов в классе внешних причин обнаружено увеличение удельного веса суицидов и уженского (на $(42,2 \pm 1,2) \%)$, и у мужского (на $(37,1 \pm 0,8) \%$ ) населения за 2009-2016 годы. Проведенное ранжирование областей государства по величине относительного риска определило территории повышенного риска по всем внешним причинам смерти и по отдельным нозологиям (ДТП, суициды, случайные отравления и действие алкоголя). Снижение риска смерти от этих причин до среднегосударственного сохранило бы жизни около 7 тысяч человек, при этом только за 2015-2016 годы упущенная выгода государства превысила бы 14 млрд. гривен. Ключевые слова: смертность, внешние причины, потерянные годы потенциальной жизни, стандартизированная структура, относительный риск, упущенная выгода.

(ㄷ Карташова С.С., Канева Т.В., Омельченко Е.М. Полька О.О. СТАТТЯ, 2018. 